\title{
LIVRO DIDÁTICO, CURRÍCULO ESCOLAR E HISTÓRIA PÚBLICA: \\ FUTURO DO PRETÉRITO
}

\author{
TEXTBOOK, SCHOOL CURRICULUM AND PUBLIC HISTORY: \\ FUTURE OF THE PAST TENSE
}

Márcia Elisa Teté Ramos ${ }^{1}$

\begin{abstract}
RESUMO: Discute as relações entre o livro didático, currículo de História e a História Pública. Considera três momentos históricos: os currículos e livros didáticos da transição da década de 1980-1990; os Parâmetros Curriculares Nacionais, de meados da década de 1990, e a contemporaneidade, com a Base Nacional Comum Curricular, em especial sobre as mudanças na organização de conteúdos históricos entre a primeira versão e a terceira versão, esta, então, vigente. Levanta hipóteses, a partir do currículo de História atual e das ideias que circulam sobre História, quanto à configuração do livro didático de História no futuro próximo. Entende que, de um lado, defende a renovação/reformulação/atualização nos conteúdos históricos escolares, mas, de outro, o passado persiste sob a ideia de cronologia linear, periodização quadripartite e conteúdos organizados de forma eurocêntrica. Considera que temos que compreender o que circula na História Pública em termos de conhecimento histórico, principalmente o que é veiculado pela mídia e, ao mesmo tempo, pensa que analisar currículo e livro didático permite uma intervenção didático-pedagógica de modo a promover uma sociedade mais democrática, justa e igualitária.
\end{abstract}

Palavras-chave: Livro didático. Currículo escolar. Ensino de História. História Pública.

\begin{abstract}
It discusses the relationships between textbooks, History curricula, and Public History. It considers three historical moments: the curricula and textbooks of the transition of the decade of 1980-1990; the National Curricular Parameters, of the mid-90's, and the contemporaneity, with the National Curricular Common Base, especially on the changes in the organization of historical contents between the first version and the third version, this being the current version. It raises hypotheses, based on the current History curriculum and the ideas that circulate about History, regarding the configuration of the
\end{abstract}

${ }^{1}$ Docente do curso de História da Universidade Estadual de Maringá, do curso de Mestrado em História Social da Universidade Estadual de Londrina e do curso de Mestrado Profissional em Ensino de História da Universidade Estadual de Maringá. 
History textbooks of the near future. It understands that, on one hand, it defends the renovation/reformulation/updating in the school historical contents, but on the other hand, the past persists under the idea of linear chronology, quadripartite periodization and organized content in a Eurocentric form. It considers that we must understand what circulates in Public History in terms of historical knowledge, especially what is conveyed by the media, and at the same time think that analyzing curriculum and textbook allow a didactic-pedagogical intervention in order to promote a more democratic society, fair and based on equality.

Keywords: Textbook. School curriculum. Teaching History. Public History.

\section{Introdução}

Assistimos um fenômeno bem interessante: a História Acadêmica, produzida por especialistas, se aparta cada vez mais daquela História que circula no senso comum. Entendemos o senso comum como os saberes construídos nas experiências, vivências, observações e interações dos sujeitos. Estes saberes são adquiridos por intermédio da família, da religião, da mídia, etc. e vão se acumulando ao longo da história pessoal e servem para que os sujeitos deem respostas para as exigências da vida prática. No caso da História, algumas noções vem circulando no senso comum: a Ditadura Civil-Militar foi branda e estabelecia a ordem social (e que, por isso, deve voltar); a escravidão brasileira replica a escravidão africana (e que, por isso, os negros não sentiriam tanto a mudança de uma escravidão para outra) e a dizimação indígena - se é que houve, segundo este tipo de perspectiva -, ocorreu apenas na época da colonização (e que, por isso, o indígena não pode ser vitimizado e "acobertado" pelo Estado na atualidade). Temos que considerar que estas ideias não ficam apenas no plano das abstrações, pois todo modo de pensar histórico se desdobra em ações que interferem na realidade. A partir destas ideias, posso entender que negros e indígenas não precisam de cotas ou qualquer política pública de inclusão, que estes se vitimizam para angariar benefícios, que o trabalho escravo hoje é necessário "porque é melhor ter qualquer emprego do que nenhum". Qualquer concepção histórica, independentemente de sua abordagem, implica em lidar com um problema do presente e organizar as pretensões para o futuro (RÜSEN, 2010b, p. 45). O passado pode ser foco, mas não se 
desprende do presente e do futuro, já que se situar numa temporalidade implica em intencionalidades. Uma forma histórica de interpretar a realidade pode "atualizar os potenciais racionais" para o reconhecimento, adoção e defesa de convicções e pretensões (RÜSEN, 2010c, p. 102) no sentido de produzir ações que possibilitem a mudança de si e do mundo, o que subentende uma perspectiva de futuro.

De um lado, alguns "historiadores" podem pensar da mesma forma que este tipo de senso comum, - assim como comentaristas, jornalistas, blogueiros, economistas, políticos, youtubers, etc. - se distanciando do que na contemporaneidade é legitimado como sendo ciência histórica, na medida em que não reconhecem/obedecem as normas que constituem/convencionam este ofício (PROST, 2008). Mesmo a escrita da História sendo um campo, no sentido posto por Bourdieu, onde os sujeitos ocupam posicionamentos diferentes e, por isso mesmo, travam disputas acerca das perspectivas históricas (multiperspectividade), as versões que hoje se familiarizam com as concepções acima mencionadas são desautorizadas por pesarem mais na "opinião" não fundamentada do que a metodologia própria da História.

De outro lado, o senso comum - ou mesmo certos materiais midiáticos - também pode se aproximar da História científica e, por isso, ser considerado coerente, mesmo se não utilizar propriamente a metodologia da História, mas os saberes experienciais. Quando o senso comum e o senso científico se coadunam, denominamos polifasia cognitiva (LAUTIER, 2011), cuja base é alcançada sob a interposição de dispositivos ${ }^{2}$ que também integram a História Pública.

Os principais dispositivos que permitem a mobilização de saberes que interligam o senso comum com a História especializada são: 1) o ensino de História na escola; 2) o livro didático; 3) museus ou acervos; 4) materiais

\footnotetext{
2 Usamos o vocábulo "dispositivo" no seguinte sentido: "um conjunto decididamente heterogêneo que engloba discursos, instituições, organizações arquitetônicas, decisões regulamentares, leis, medidas administrativas, enunciados científicos, proposições filosóficas, morais, filantrópicas. Em suma, o dito e o não dito são os elementos do dispositivo. O dispositivo é a rede que se pode tecer entre estes elementos" (FOUCAULT, 2000 , p. 244).
} 
midiáticos como programas de televisão, jornais, documentários, filmes e livros (ALBIERI, 2011), e acrescentamos o item 5) currículo escolar de História. Estas mediações para se construir um pensamento mais fundamentado na ciência histórica, podem parecer não estar cumprindo seu papel na atualidade brasileira, visto as noções pseudo-históricas em circulação vinculadas ao preconceito, à estereotipia, à intolerância ou mesmo à violência. Contudo, há que se entender que estes materiais/espaços concorrem com outros na construção da História Pública que talvez sejam mais conviventes e atraentes ao universo cultural do público como aquele presente nas redes sociais. No caso do presente texto, trabalharemos os pontos 2 (currículo), 4 (mídia) e 5 (currículo), o que será explicado mais adiante ao tratarmos da História Pública como campo de pesquisa.

A História Pública não significa o lugar em que circula apenas o senso comum ou o conhecimento estritamente não-científico, mas é um amálgama de dispositivos constitutivos dos saberes, incluindo estes materiais/espaços intermediários citados no parágrafo anterior. Ao nosso ver, os currículos ou os livros didáticos não podem ser vistos, meramente, como provenientes do conhecimento não especializado, bem como saberes que transpõem, didaticamente, o saber acadêmico para o saber escolar, tal qual querem vertentes investigativas no campo da aprendizagem histórica baseadas em determinada leitura de Chevallard (1991). O currículo e o livro didático, por exemplo, são produto da História Pública, mas, também, veículos de intervenção nas ideias históricas que circulam nesta esfera, mesmo que de forma indireta por serem intermediados pela atuação/interpretação dos agentes escolares com seus códigos socioculturais.

O campo investigativo da História Pública nasce na década de 1970, concomitante ao campo da Didática da História, sendo o primeiro nos Estados Unidos e o segundo na Alemanha. As preocupações são próximas, voltadas, resumidamente, para o entendimento de como as pessoas pensam o passado. Para Rüsen (2010), a Didática da História procura 
compreender a cultura histórica como "manifestação da consciência histórica na sociedade", que "inclui o trabalho cognitivo dos estudos históricos, bem como as atitudes da vida cotidiana voltadas para a compreensão do passado" e, ainda, a "educação histórica nas escolas" e "as apresentações do passado nas diversas mídias ou na literatura" (RÜSEN, 2010a, p. 24). Argumenta Bergmann (1990) que a preocupação da Didática da História está voltada para a investigação sobre: o que é apreendido no ensino de História (ação empírica, cujo objetivo é abranger a elaboração da História e sua compreensão, tanto no ambiente acadêmico, como na escola ou em outras esferas sociais), o que pode ser apreendido (reflexão sobre os interesses, problemáticas, pressupostos, teorias, métodos, formas de exposição), o que deveria ser apreendido (tarefa normativa, que enfoca as formas de mediação intencional e da representação ou exposição da História) (BERGMANN, 1990, p. 29-31). No caso da História Pública, Roy Rosenzweig e David Thelen (1998) citam associações científicas que pesquisaram a nível nacional - como a National Council on Public History, criada em 1979 - sobre o que o público tem a nos dizer quanto ao passado, - que se imbricava com a forma pela qual as pessoas interpretavam materiais que traziam determinado conhecimento do passado: literatura infantil, filmes, revistas, museus, livro didático, etc. Logo se constatou que o público norte-americano respondia a estes materiais sobre o passado, por vezes, de forma diferente do que esperavam seus produtores, conforme suas personalidades, vivências e tradições coletivas (ROSENZWEIG; THELEN, 1998) ${ }^{3}$.

Embora o campo da História Pública venha sendo consolidado no Brasil, recentemente, abriga uma série de vieses que nos fazem concordar com o argumento pelo qual antes mesmo de se falar nele, este campo já existia, desde, pelo menos, os trabalhos com História Oral e a História do

3 Segundo Bruno Flávio Lontra Fagundes (2017, p. 3019), "Henri Rousso (1984) pesquisa as origens francesas da Public History na França e as identifica ainda nos anos 1930 na origem da Sociologia e da Economia, que, segundo o autor, 'conheceram um progresso considerável [...] graças à pesquisa contratual' para empresas e governos". Para saber mais sobre a trajetória histórica e uma definição mais completa do campo da História Pública, ver Fagundes (2017). 
Tempo Presente (ALBIERI, 2011). Campo que vem se transformando em disciplina acadêmica de cursos de graduação ${ }^{4}$, cursos/eventos ${ }^{5}$, cursos de pós-graduação ${ }^{6}$, etc. Criou-se, também, em 2011, a Rede Brasileira de História Pública (RBHP), que já realizou o seu quarto simpósio, ocorrido na Universidade de São Paulo (USP), em agosto de 2018. Houve, também, eventos regionais e o aumento de simpósios temáticos sobre História Pública nos eventos nacionais de História.

A História Pública não exclui objetivos da Didática da História, mas enfatiza dois elementos desde o seu surgimento para além daquele de pesquisar os usos e funções da História em determinada cultura histórica: 1) pensa, também, na própria produção da História Pública. A Didática da História parte da reflexão sobre a Teoria da História, enquanto o campo investigativo da História Pública esteve relacionado diretamente à vida prática, pois se concebe um profissional capaz de produzir lugares, materiais, documentários, exposições museais, livros didáticos, etc. que permitam a democratização do acesso público ao conhecimento histórico especializado. Procura-se, então, pesquisar/analisar/entender como as pessoas pensam o passado, como se apropriam dele, ou seja, realiza um diagnóstico, mas abre à preocupação em utilizar os resultados da pesquisa

\footnotetext{
4 "Desde o final dos anos 1990, nos Estados Unidos, a Public History encontra-se institucionalizada dentro das universidades. Em 1996, o National Council on Public History $(\mathrm{NCPH})$ já arrolava mais de cinquenta programas de pós-graduação (graduate studies, nosso Stricto Sensu) voltados, em geral, para cursos principais em História e Administração Pública com habilitações em áreas como História Oral, Administração de Arquivos, Planejamento Urbano e História Ambiental. As universidades católicas estão na ponta do processo. A Howard University, em Washington D.C., sustenta a Association for the Study of Afro -American Life and History; já a Middle Tennessee State University, próxima a Nashville, mantém tanto a Country Music Foundation como a famosa Graceland, em Memphis. Entre os postos de trabalho conquistados por estudantes formados destacam-se o gigante National Park Service (NPS) e a Smithsonian Institution, a US Senate Historical Office, assim como o Wells Fargo Bank, o Gene Autry Museum e o Lower East Side Tenement Museum, em New York (NCPH 1996; RITCHIE 2001)" (MALERBA, 2014, p. 29-30).

5 Como o curso "Introdução à História Pública" ministrado na USP em 2011, organizado por Juniele Rabêlo de Almeida e Marta Rovai que resultou no livro intitulado da mesma forma (ALMEIDA; ROVAI, 2011).

6 No Reino Unido, Oxford foi pioneira em questão de História Pública institucionalizada, no Ruskin College. A universidade "oferece um Mestrado em História Pública, enquanto outras instituições dão cursos em história aplicada [...] ou estudos de patrimônio [...] com um componente de história pública." (LIDDINGTON, 2011, p. 32). No Brasil temos o Mestrado Acadêmico em História Pública da UNESPAR - Campo Mourão. Ver: http://unespar.edu.br:8081/PPGHP.
} 
para se fazer/produzir um prognóstico, com vistas a fazer História Pública. Isto significa atuar na difusão e construção do conhecimento histórico para "audiências" mais amplas, o que demanda habilidades, métodos e especializações próprias, na área de preservação, de difusão e ensino extraescolar (SANTHIAGO, 2016). Nesta direção, o livro didático é considerado produto da História Pública, ou seja, não confeccionado, necessariamente, pelos professores universitários, mas, também, é um objeto a ser (re)pensado para que seja um veículo de intervenção na aprendizagem histórica, ou seja, na História Pública, o que deveria requerer um tipo de expertise adequado a esta intencionalidade.

No caso do livro didático de História, além do conhecimento histórico baseado na historiografia ou na metodologia da História, cumpre entender, entre outros: como os estudantes aprendem ou realizam a progressão do conhecimento histórico através do livro didático; como os professores o utilizam, ou quais livros didáticos preferem; que tipo de estética e diagramação otimiza sua leitura; quais linguagens e imagens podem resultar em um trabalho didático-pedagógico mais satisfatório; quais conceitos históricos são importantes e como devem ser trabalhados, conforme determinada faixa etária; se o livro didático adotado está condizente, ou não, com a realidade regional dos estudantes, da escola; quais, porque e como as leis/diretrizes devem ser inseridas no livro didático. São conhecimentos que demandam a interdisciplinaridade entre História, Educação, Sociologia, Editoração e Comunicação, mas que, ao mesmo tempo, são específicos para a produção e avaliação do livro didático de História. Até o momento, não temos uma preparação adequada para se fazer História Pública por intermédio do livro didático: os autores de livros didáticos têm apenas os editais do Programa Nacional do Livro Didático $(P N L D)^{7}$ como parâmetro para orientá-los, os quais recorrem ao currículo

\footnotetext{
7 O Programa Nacional do Livro Didático (PNLD) é a mais antiga política de Estado voltada à distribuição de obras didáticas aos estudantes da rede pública de ensino brasileira e iniciou-se, com outra denominação, em 1937. Ao longo desses 80 anos, o programa foi aperfeiçoado e teve diferentes nomes e formas de execução. Atualmente, o PNLD é voltado à educação básica brasileira, tendo como única exceção os alunos da educação infantil.
} 
vigente, enquanto os avaliadores têm as fichas de avaliações, pois não existe um corpo de conhecimentos próprio para o exercício das funções supramencionadas. Entretanto, não é este primeiro diferencial que move a presente pesquisa, mas o segundo.

2) os estudos de História Pública privilegiam as mídias como configuradoras da cultura histórica (ROSENZWEIG; THELEN, 1998). No Brasil se tem explorado, em especial, os dispositivos midiáticos autointitulados "revisionistas", que constroem uma história sensacionalista, denunciando "erros", sendo, grande parte, conservadora. Gerald Zahavi (2011, p. 53) escreve que este tipo de História Pública "é uma arena de disputas vigorosas, na qual adversários ideológicos lutam pelo legado, patrimônio e memória pública de acontecimentos ocorridos há muito ou há pouco tempo, e que ainda estão de desdobrando". O público consumidor de História vem crescendo nos últimos anos, criando uma demanda social por História. Uma demanda que não está sendo suprida pelos historiadores brasileiros que dificilmente produzem para fora da academia, deixando o espaço aberto para jornalistas, documentaristas, cineastas, romancistas, divulgarem versões historiográficas com grande penetração na cultura (ALBIERI, 2011, p. 23).

Considerando este segundo ponto, entendemos que nossa discussão sobre as articulações entre currículo de História e livro didático de História envolve, também, a opinião da mídia. Em um movimento tensional recursivo, a mídia se propõe a interferir no currículo de História, e, consequentemente, na elaboração dos livros didáticos, dizendo/defendendo/requerendo determinados saberes que considera importantes de serem ensinados, de acordo com o que entende sobre Educação, ensino, História e sociedade.

Neste artigo, consideramos as interfaces entre livro didático de História, currículo escolar, e mídia, em três momentos: a transição da década de 80 para a 90 do século passado, que engendrou currículos em cada Estado; os Parâmetros Curriculares Nacionais (PCNs) de meados da década de 1990, que adotam políticas internacionais para Educação e, 
finalmente, a atualidade, com as versões curriculares de História da Base Nacional Comum Curricular (BNCC) 2015-2017. Neste último momento, por estar ainda em curso, nos detemos nos limites e possibilidades do que, efetivamente, na análise de um livro didático específico.

\section{Transição das décadas de 1980-1990: pedagogia histórico- crítica}

Em São Paulo, o processo de revisão curricular, entre os anos de 1982 e 1992, contou com a Coordenadoria dos Estudos e Normas Pedagógicas (CENP). Segundo Maria do Carmo Martins (1998), a proposta curricular de História deu margem à controvérsia devido à postura de um grupo afeito à Pedagogia histórico-crítica e, portanto, foi construída em um prazo mais longo do que a das demais disciplinas. Os currículos da época, em grande parte, se baseavam no currículo de São Paulo. Em Minas Gerais, o programa de História para $1^{\circ}$ e $2^{\circ}$ graus foi publicado em 1986, e o de Rio de Janeiro, em 1988, enquanto que no Paraná, o currículo para Educação Básica publicou-se em 1989. Quando nos referimos à Pedagogia históricocrítica, entendemos a importância do educador Demerval Saviani, conhecido por transferir a concepção gramsciniana para a realidade escolar brasileira, no sentido de organizar os conteúdos escolares de forma a dar condições, aos educandos, de terem acesso ao conhecimento acumulado da humanidade $e$, consequentemente, instrumentos de luta contra a exploração.

Em acordo com o contexto de contraposição às políticas curriculares dos sucessivos governos militares, o interesse voltava-se para duas correntes diferentes: ou para os movimentos sociais, o trabalho como categoria histórica, as relações socias (SCHMIDT, 2005, p. 40), conforme referencias marxistas e/ou histórico críticos, ou, ainda, sob a égide da Nova Historiografia Inglesa (RAMOS, 2015); ou para metodologias mais comprometidas com a Escola dos Annales (SCHMIDT, 2005, p. 40) e/ou com a Nova História, que compreendiam assuntos ligados ao cotidiano e à 
cultura. Combinando a vertente pedagógica com a historiografia, construiuse a ideia de que se deveria ensinar "toda a História", todo passado humano, bem como a adoção de um referencial (neo)marxista com algumas incursões pela cultura.

A meta seria opor-se a um ensino de História tradicional/convencional ${ }^{8}$, eurocêntrico, quadripartite e factual. Entretanto, a esperada renovação não aconteceu, pois prevaleceu uma linha temporal sequenciada e "progressiva", mesmo que outros parâmetros sustentassem tal currículo. No Currículo Básico do Paraná (PARANÁ, 1990), um ordenamento estrutural se repetia conforme uma reflexão sobre temas como: as condições de trabalho; a participação dos trabalhadores; a legislação trabalhista; os tipos de propriedade, realçando o problema da exploração e da dominação no transcurso histórico. Também se verifica que os conteúdos exibiam a História em um movimento cíclico de modo de produção (embora o conceito não seja mencionado no caso do currículo paranaense), os quais envolviam: formação, ou origem (subtema da 6a série: "A construção do Estado Nacional"); contradições (subtema da $5^{a}$ série: "Contradições do sistema colonial"; $8^{a}$ série: "Contradições do capitalismo") e conflitos, crise ou desintegração (subtema da $5^{\text {a }}$ série: "Contestação e crise na colônia"; tema da $8^{a}$ série: "Contradições e contestações ao capitalismo monopolista"). Percebe-se a continuidade da história cronológica e eurocêntrica, e ainda, quadripartite em outros moldes: modo de produção primitivo, escravista, feudal e capitalista (tendo o asiático como um tipo de exceção).

O currículo de São Paulo optou por trabalhar o ensino de História através de eixos temáticos, buscando se diferenciar da predominância do modelo quadripartite francês ou da evolução dos modos de produção. No

\footnotetext{
${ }^{8}$ Se convencionou entender a chamada História Tradicional na História do Ensino de História conforme Elza Nadai (1993): memorização e a aula expositiva como método de ensinoaprendizagem; o conhecimento histórico como verdade obtida através da neutralidade e objetividade do historiador; tempo histórico associado à cronologia linear-evolutiva; história nacional que buscava identificação com a civilização europeia e o destaque dado aos eventos políticos, à ação de indivíduos extraordinários (em geral, homens, brancos e cristãos) e à contribuição, sem conflitos, de brancos, negros e indígenas na formação e progresso da nação.
} 
entanto, encaixou a categoria trabalho em todos os eixos temáticos: "O Trabalho: diferentes formas de vida - diferentes formas de trabalho" e "O Trabalho: terra-propriedade/cidade-fábrica: resistências cotidianas" ${ }^{\prime 9}$.

Integrava o movimento de oposição ao currículo de História associado às políticas educativas do regime militar, colocar o livro didático, em especial o de História, como "objeto de suspeição", denunciando suas supostas distorções e depreendendo o caráter "reacionário" dos conteúdos históricos que veiculava (MUNAKATA, 1998). Vários escritos problematizavam o livro didático, entre os quais: "As belas mentiras: a ideologia subjacente aos textos didáticos" (1981) de Maria de Lourdes Chagas Deiró Nosella, "O Livro Didático em Estudos Sociais" (1986) de Eloísa de Mattos Höfling; o caderno CEDES com o tema "O cotidiano do livro didático" (1987) e "A ideologia no livro didático" (1987) de Ana Lúcia G. de Faria. Quanto ao livro didático de História, em "História em quadro-negro" (1990), Arthur Soffiati sublinhava as suas inovações, marcando o referencial teórico mais comum na época: "Passou-se a trabalhar com as categorias de modo de produção, estrutura, conjuntura e acontecimento", ao mesmo tempo em que se procurava "penetrar, ainda que timidamente, nos terrenos baldios do cotidiano, do imaginário, das atitudes mentais, das sensibilidades" (SOFFIATI, 1990, p. 44). Perspectiva diferente de Ana Lúcia Faria nesta revista, pois entendia que o livro didático "sintetiza a ideologia burguesa, amortiza o conflito realidade $x$ discurso, dizendo que o verdadeiro é o segundo" (FARIA, 1987, p. 77).

Exemplificando os desdobramentos desta crítica ao modelo do livro didático imputado aos governos militares, tivemos os livros didáticos escritos por Elza Nadai e Joana Neves (1991b, 1991c), dos quais destacamos: História Geral: Antiga e Medieval, 5a edição de 1991 e História Geral: Moderna e Contemporânea, $8^{a}$ edição de 1991, para $2^{\circ}$ grau (hoje, Ensino Médio) $)^{10}$. Algumas regularidades, em termos conceituais, nos

\footnotetext{
9 Vê-se, assim, que a História Temática já era proposta antes mesmo dos PCNs, como veremos mais à frente.

10 O currículo do Paraná, aqui tomado de exemplo, refere-se ao primeiro grau e os livros didáticos de Elza Nadai e Joana neves são designados para o segundo grau.
} 
mostram uma abordagem mais voltada para o nível econômico, da infraestrutura, o que caracteriza uma perspectiva marxista. Os títulos e subtítulos dos capítulos permitem perceber a ideia de modo de produção, baseado em origem/apogeu/crise: "O Papado: preponderância e crises"; "A crise dos séculos XIV e XV" (NADAI; NEVES, 1991b); "O século XIX: o triunfo burguês"; "A sociedade liberal: apogeu, crises e revolução"; "O proletariado"; "O período entre-guerras: as democracias liberais e crises" (NADAI; NEVES, 1991c); Também podemos ver uma concepção baseada na economia, na infraestrutura: "A sociedade feudal: estrutura econômica" (NADAI; NEVES, 1991b).

Em História do Brasil: da Colônia à República de 1991, as autoras Nadai e Neves (1991a) seguiam a mesma linha de composição dos conteúdos, considerando o modo de produção e/ou uma visão economicista, frisando as relações de poder e a exploração, assim temos "Apogeu e crise do sistema colonial", como um dos capítulos; "A organização sócioeconômica e a persistência colonial", como um dos subtítulos; e, como leitura complementar, "Uma reforma agrária à avessas", um texto de 1986 de Ricardo Abramovay intitulado "O velho poder dos barões da terra" (NADAI; NEVES, 1991a, p. 79).

A bibliografia utilizada, neste livro didático como em outros, pode ser considerada marxista: no História Geral 1 (NADAI; NEVES, 1991b): Passagens da Antiguidade ao Feudalismo de Perry Anderson (1982); História da riqueza do homem de Leo Huberman (1973); Modo de produção na Antiguidade organizado por Jaime Pinsky (1982); no História Geral 2 (NADAI; NEVES, 1991c): Capitalismo monopolista: ensaio sobre a ordem econômica de Paul Baron e Paul Sweezy (1978); Trabalho e capital monopolista de Harry Braverman (1981); A evolução do capitalismo de Maurice Dobb (1977); História da riqueza do homem de Leo Huberman (1973); Le marxisme em Amérique Latine: de 1909 à nos jours: anthologie de Michael Lowy (1980); Da guerrilha ao socialismo: a revolução cubana de Florestan Fernandes (1979). Embora já se via bibliografia voltada para

Entendemos que não há discrepância nos princípios, pressupostos e referenciais entre um nível de ensino e outro. 
História Cultural e/ou Escola dos Annales, no História Geral 1 (NADAI; NEVES, 1991b), temos Georges Duby, Jacques Le Goff, e no História Geral 2 (NADAI; NEVES, 1991c) são poucos os livros que podem ser considerados como apresentando uma abordagem mais renovada, porém, ainda relacionados ao marxismo ou neomarxismo, como René Remond.

As capas destes livros, acima referidos, apresentam desenhos de diversos rostos que nos dá a impressão de serem trabalhadores, o que mostra a concepção das autoras: "uma concepção de História que tenta romper com a visão dos grandes feitos e grandes personagens [...] a História como uma construção coletiva, em que o próprio anônimo, e não somente as grandes personalidades, têm o seu espaço" (SALLES, 2017, p. 301).

A mídia tem se ocupado em levantar questões relacionadas ao ensino e aprendizado histórico. Quando, na discussão sobre a Proposta Curricular de São Paulo pela CENP, cuja concepção fundamentava os currículos de outros Estados e os livros didáticos de História, a mídia iniciou uma série de críticas. Cláudia Ricci (1998) destaca que a proposta curricular da CENP foi avaliada de forma negativa por, aproximadamente, 50 artigos e editoriais de jornais da grande imprensa, principalmente pelos jornais Folha de São Paulo, O Estado de S. Paulo e Jornal da Tarde. Considerada uma proposta "da esquerda radical", o jornal O Estado de S. Paulo, em maio de 1987, noticiou - "Ainda a marxização do ensino" -, enquanto que, em julho do mesmo ano, a Folha de São Paulo atacou a proposta com o editorial - " $A$ ignorância no poder". Este anunciou, em 30 de julho de 1987, que o ensino de História teria se reduzido a uma questão de "dominação e resistência". Para a pesquisadora, essas matérias jornalísticas acabaram por impingir certa maneira das delegacias de ensino de interpretarem a proposta curricular como "tendenciosa", "marxista", "altamente socializante", "extremamente radical", "esquerdista".

Os livros didáticos próximos à base marxista, como já dissemos, atrelados à forte oposição aos livros didáticos produzidos/utilizados nos governos militares, tiveram um prazo de uso relativamente curto, embora 
no próximo parágrafo apresentamos uma obra de base marxista usada de 1998 a 2007. O próprio campo de discussão sobre ensino e aprendizagem histórica passou a revisar a concepção que embasava tais livros. Em 1988, criticando os currículos histórico-críticos, publicou-se "O ensino de história e a criação do fato", em que os autores questionavam se as reformas educacionais, da transição da década de 1980 para a década de 1990, teriam realmente superado o ensino tradicional de História. Entre eles, Jaime Pinsky considerava que a substituição do positivismo pelo marxismo de ênfase economicista terminou por deixar o homem, "razão última do estudo histórico engajado", esquecido diante do "processo histórico" e/ou das "razões econômicas" (PINSKY, 1992, p. 19).

Não podemos tomar estes três momentos de reformulação curricular e, portanto, do livro didático, aqui postos, como fases estanques. De 1998 a 2007, temos a coleção Nova História Crítica para o Ensino Fundamental 2, em especial o livro para $8^{a}$ série, escrita por Mario Schmidt, com embasamento marxista. Livro que causou várias críticas, especialmente do jornalista Ali Kamel, no jornal O Globo de 18 de setembro de 2007. A Abril entrou no mercado de livros didáticos e cursos apostilados através de uma nova divisão, na qual incorporou as editoras Ática e Scipione e era de interesse "derrubar" as vendas de Nova História Crítica, o que foi conseguido. Kamel (2007) denuncia a coleção como indutora da subversão, do marxismo: "Nossas crianças estão sendo enganadas, a cabeça delas vem sendo trabalhada, e o efeito disso será sentido em poucos anos. É isso o que deseja o MEC? Senão for, algo precisa ser feito, pelo ministério, pelo congresso, por alguém" (KAMEL, 2007) ${ }^{11}$. Embora tenha sido reprovado pelo PNLD de 2008, o livro foi citado - bastante na revista Veja, sob a regência de Reinaldo Azevedo - como prova de que a escola seria doutrinadora de esquerda. ${ }^{12}$

As abordagens dos currículos e livros didáticos, apesar de serem compreendidas como inovadoras para a época, ainda trazem indícios

\footnotetext{
11 Ver a excelente análise sobre a crítica à forma como a mídia tratou esta coleção: Umbelino (2017) e Ana Paula Sousa, em Carta Capital de 1 de outubro de 2007, expôs o porquê da "guerra de narrativas" que colocava este livro didático como vilão (LIMA, 2017). 12 Azevedo (2007a, 2007c, 2007d, 2007e, 2007f).
} 
daquilo que caracteriza o ensino de História tradicional. Ainda prevalece a organização dos conteúdos baseados na concepção eurocêntrica, quatripartite, cronológica e linear, inclusive se utilizando de palavras como "causas" e "consequências"13. Contudo, o mérito de tais currículos/livros foi a tentativa de trazer a visão crítica-problematizadora da realidade, denunciando a exploração e a desigualdade/injustiça social ${ }^{14}$.

\section{Os parâmetros curriculares nacionais: História temática/uso escolar das fontes}

Os PCNs de História procuravam distanciar-se dos currículos históricocríticos, pautados nos "modos de produção com influência marxista, que enfatizavam transformações econômicas e conflitos entre as classes sociais", onde predominaria "uma abordagem estruturalista na qual a História era estudada como consequência de estágios sucessivos e evolutivos". Contudo, procuravam não descartar a sua "contribuição" por criticar a "História que valorizava o político e a sua trajetória vitoriosa da classe burguesa na consolidação harmoniosa do mundo moderno" (BRASIL, 1997 , p. 24).

13 Ressalvando que, no caso, causas e consequências, embora conceitos importantes para que o estudante entenda a História, são tratadas como se passado, presente e futuro fossem compostos por acontecimentos evolutivos. Destitui-se, assim, a História vista como processo, tanto de permanências como de mudanças. Nesta perspectiva, a multicausalidade também é silenciada, ou seja, não se vê que um fato pode ter várias causas e desdobramentos. Este modelo de entendimento da História baseia-se no positivismo, sistema criado por Auguste Comte (1798-1857) que, ao propor as ciências experimentais como referência por excelência do conhecimento humano, provocou a ideia de que a História seria ordenada por determinadas leis que levariam sempre ao progresso.

14 Quanto à avaliação do livro didático desta época, em 1983, em substituição à Fename, é criada a Fundação de Assistência ao Estudante (FAE), que incorpora o Programa do Livro Didático para o Ensino Fundamental (Plidef). Na ocasião, o grupo de trabalho encarregado da avaliação dos livros didáticos propõe a participação dos professores na escolha dos livros e a ampliação do programa, com a inclusão das demais séries do ensino fundamental. Em 1985, com a edição do Decreto no 91.542, de 19/8/85, o Plidef dá lugar ao Programa Nacional do Livro Didático (PNLD), que traz diversas mudanças, como: indicação do livro didático pelos professores; reutilização do livro, implicando a abolição do livro descartável e o aperfeiçoamento das especificações técnicas para sua produção, visando maior durabilidade e possibilitando a implantação de bancos de livros didáticos; extensão da oferta aos alunos de $1^{a}$ e $2^{a}$ série das escolas públicas e comunitárias; fim da participação financeira dos estados, passando o controle do processo decisório para a FAE e garantindo o critério de escolha do livro pelos professores. 
O volume de História dos PCNs procurou aliar os objetivos do Ensino Fundamental estabelecidos na Introdução, embasados na linha didáticopedagógica Construtivista - citando como referência bibliográfica Paulo Freire, Freinet, Vygotsky, e Perrenoud - com as reflexões realizadas por "pesquisadores e produtores de conhecimento historiográfico" (BRASIL, 1998 , p. 29). Mas há uma diferença entre o que estava posto na Introdução e o tomo de História. Este conseguia se desprender, em parte, da concepção sobre Educação baseada em competências, o que era algo mecânico/técnico, mas ainda carregava alguns problemas. Os PCNs, em especial, a parte introdutória, mostravam que algumas palavras ou expressões, bastante utilizadas no currículo histórico-crítico, eram "erradicadas". Comparando os currículos de História das décadas de 1980/1990 com os PCNs de História, pode-se notar que: se antes as relações históricas de exploração e dominação do passado deveriam ser compreendidas pelos aprendizes para que estes as percebessem no presente, nos PCNs, tais relações foram situadas no passado, sendo que o grande problema com o qual todos deparavam, certamente, era o desemprego (BRASIL, 1998, p. 37, 68); as relações sociais nos currículos histórico-críticos eram vistas como conflituosas e envolviam posições econômicas, políticas e culturais díspares, enquanto nos PCNs utilizava-se o prefixo "inter" sugerindo reciprocidade, ou seja, as relações sociais tornavam-se "papéis interpessoais e intergrupais" (BRASIL, 1998, p. 31); as lutas reivindicatórias ou movimentos sociais, destacados na elaboração e na prescrição curricular anterior, tornavam-se, nos PCNs, "resistências cotidianas" (BRASIL, 1998, p. 31).

Naquele momento, quando se falava em "construção" ou "produção" do saber ou do conhecimento histórico em sala de aula, perspectivava-se a "transposição didática", conceituada por Chevallard (1991) como o trabalho de fabricar um objeto de ensino, ou seja, transformar o saber produzido pelo "sábio" (o cientista) em saber escolar. Procurava-se, então, discutir formas de se compatibilizar o saber escolar com o saber científico de referência e/ou acadêmico para que não se tornasse obsoleto, 
aproximando-se do senso comum (CHEVALLARD, 1991, p. 30-31). Esta transposição didática nos PCNs de História, quando relacionada ao Construtivismo tornou-se a transposição do fazer, da criticidade do historiador para a sala de aula, através do emprego das fontes documentais, o que se coadunava com as discussões no campo do ensino e aprendizagem histórica. Também se defendia a ideia de se explorar a História Temática, então apresentada nos PCNs como "eixos norteadores" da organização de conteúdos históricos. Os PCNs de História entenderam que o saber histórico escolar se configura pela recriação da ciência de referência para fins didáticos, unindo História Nova e Construtivismo (BRASIL, 1998, p. 30).

Neste processo, duas coletâneas foram fundamentais: "Repensando o ensino de história" (1996), de Sonia Nikitiuk, e "O saber histórico em sala de aula" (1997), organizado por Circe Bittencourt, marcaram as discussões sobre a disciplina histórica escolar, não mais criticando diretamente a Pedagogia histórico-crítica ou o marxismo no ensino, mas enfocando a produção do saber histórico em sala de aula, a partir dos documentos e/ou da discussão sobre a necessidade de a reestruturação curricular englobar o ensino pela pesquisa História Temática.

Os PCNs apresentavam os conteúdos históricos por eixos temáticos: para o $1^{\circ}$ ciclo ( $1^{\circ}$ e $4^{\circ}$ anos), "História local e do cotidiano"; para o $2^{\circ}$ ciclo (30 e $4^{\circ}$ anos), "História das organizações populacionais"; para o 30 ciclo (na época, $7^{a}$ e $8^{a}$ séries), "História das relações sociais, da cultura e do trabalho"; e, para o $4^{0}$ ciclo (na época, $5^{a}$ e $6^{a}$ séries), "História das representações e relações de poder". O professor deveria trabalhar com o pressuposto historiográfico que lhe conviesse, e no subtema "As relações sociais e a natureza", do $3^{0}$ ciclo, era oferecido um exemplo de como poderia ser trabalhado o recorte "alimentação", por intermédio de dados que deveriam ser retirados de documentos, tais como relatos de viajantes, desenhos e pinturas (BRASIL, 1998, p. 56): destacava-se o cotidiano da alimentação em diferentes épocas históricas, como os alimentos eram 
obtidos e consumidos em diferentes sociedades, a identificação sobre se eram naturais ou industrializados, como eram preparados.

Para os PCNs de História, os temas deveriam ser explorados com o auxílio das fontes históricas: a "análise do documento nos seus detalhes", pela confrontação entre os documentos, a sua "inserção nos contextos de época", "os questionamentos quanto às suas contradições e coerências internas", que permitiriam ao estudante, "conquistar procedimentos e atitudes de pensar/refletir historicamente" (BRASIL, 1998, p. 86). Os PCNs explicavam, em detalhes, como trabalhar uma fonte documental, e tomavam a prancha $O$ colar de ferro - castigo dos fugitivos, de Jean Baptiste Debret, como exemplo.

Podem representar a noção de História Temática da época a coleção sob o mesmo título, escrita por Andrea Montellato, Conceição Cabrini e Roberto Catelli Junior (2000). Divide-se em quatro temas, correspondentes às séries do Ensino Fundamental 2: Tempos e Culturas ( $5^{a}$ série); Diversidade Cultural e Conflitos (6 $6^{a}$ série); Terra e Propriedade (7a série) e O Mundo dos Cidadãos ( $8^{a}$ séries).

As capas desta edição de 2000 e das subsequentes também são significativas para entendermos a concepção de História dos autores: uma escultura, representando um rosto, ocupa o espaço da capa com fundo branco, dimensiona o tema que será tratado no volume.

A coleção História Temática, diferentemente dos livros didáticos de autoria de Elza Nadai e Joana Neves, mostra composições bem diferentes, não apenas quanto à abordagem, mas quanto ao tratamento das imagens e fontes. Isso, mesmo se consideramos que são livros que correspondem à níveis de ensino diferentes. Lembrando que estas mudanças acompanham o contexto histórico, a historiografia, o campo didático-pedagógico, bem como os avanços tecnológicos no campo da produção dos livros. As imagens se tornam coloridas, não meramente ilustrativas ou complementares, mas consideradas como fontes históricas a serem interpretados pelos alunos. As atividades são mais complexas: enquanto que nos livros de Elza Nadai e Joana Neves, a chamada Proposta de Estudo implicava em questionário, a 
coleção Histórica Temática traz imagens, documentos, mapas, músicas, etc, para serem analisadas e, por vezes, debatidas.

Praticamente desaparecem os referenciais de cunho marxista e são inseridos livros voltados para a História Cultural (Jacques Le Goff, por exemplo). Se vê indicação de livros paradidáticos ou literatura infantojuvenil, clássicos, coletâneas de documentos, e uma bibliografia de orientação construtivista, juntando livros destinados ao aluno e ao professor. Literatura: A meio ao contrário de Ana Maria Machado (1985); Como escrever no deserto de Anita Ganeri (1995). Paradidáticos: A Civilização Maia de Paul Gendrop (1987). Construtivismo: Pensamento e Linguagem de Vygotsky (1995). Aprendizagem escolar e construção do conhecimento de César Coll (1994); O raciocínio da criança de Piaget (1987). Coletâneas de documentos: 900 textos e documentos de história de Gustavo de Freitas (1977). Permanecem poucos autores ligados ao marxismo, como Leo Huberman, em História da Riqueza do Homem de (1973).

Outro livro baseado na História Temática e que conjuga o emprego de fontes históricas é Brasil: uma história em construção, em dois volumes, escritos por José Rivair Macedo e Mariley W. Oliveira, então distribuídos, em 1996, pelo governo do Paraná, através do Projeto alternativa. Enquanto que os PCNs, como dissemos, pareciam despolitizar os conteúdos, inclusive com o exemplo que dava sobre História da alimentação ao não problematizar a fome, os livros didáticos de História poderiam ir na contramão e abordar temas polêmicos, como no livro agora mencionado. No sexto capítulo, denominado 0 país dos "mortos vivos": concentração de renda e miséria no Brasil, do volume 2, os autores questionam o país da fome. No texto didático, ou no poema de Manuel Bandeira, Estrela da vida inteira (MACEDO; OLIVEIRA, 1996, p. 55), na imagem da criança desnutrida chorando de fome e reportagens de dois jornais (MACEDO; OLIVEIRA, 1996, p. 56), na estatística (MACEDO; OLIVEIRA, 1996, p. 56) e infográfico (MACEDO; OLIVEIRA, 1996, p. 57), na historiografia (MACEDO; OLIVEIRA, 1996, p. 59), no retrato (MACEDO; OLIVEIRA, 1996, p. 61) e depoimento 
de Betinho (MACEDO; OLIVEIRA, 1996, p. 62), na indicação de livros e filmes (MACEDO; OLIVEIRA, 1996, p. 63), entre outras tantas fontes, se discute a fome, a miséria, a situação do país. Atividades que fazem o aluno refletir, debater sobre hábitos de consumo, pessoas que moram e vivem do lixão, o livro demonstra a preocupação em construir os eixos temáticos de urgência social. Destoando dos PCNs, que talvez sejam inovadores em muitos aspectos, mas não em torno de uma crítica social mais profunda, o livro recupera a História pelo viés da política, ou melhor, do posicionamento político, da problematização da realidade através das fontes.

Como nos PCNs, nestes livros, acima comentados, são enfatizadas as solicitações de exploração/interpretação das fontes históricas, o que não significa que uso de fontes e História Temática fossem elementos combinados em todos os livros didáticos. Exemplificamos com a coleção História em Documento: Imagem e texto de Joelza Ester Domingues (2001), designado para a $5^{a}$ à $8^{a}$ série, que se centraliza nas fontes históricas, até mesmo secundarizando o texto didático, mas segue uma cronologia tradicional. No Manual do Professor, existe minuciosa orientação de como se tratar das fontes históricas do Livro do Aluno. Nesta coleção, percebemos que as referências se ampliam para dicionários, ensaios, atlas, coletânea de documentos, etc., o que aponta para um interesse pela pesquisa e/ou interpretação de fontes históricas. Também é perceptível a diagramação que traz gêneros textuais diversificados, formando organicidade. São boxes, trechos de historiografia e várias fontes. No início de cada unidade, procura-se recuperar o conhecimento prévio do aluno, mediante a seção Diga o que você sabe, fomentando a relação presentepassado, como, por exemplo, no livro para oitava série sobre o Antigo Regime, onde se apresenta a Estátua da Liberdade norte-americana com as seguintes perguntas: "Você conhece esta estátua? Que objetos ela segura nas mãos? O que eles simbolizam? Que relação poderia haver entre o título da unidade e o simbolismo dessa estátua?" (DOMINGUES, 2001, p. 10). As capas, compatíveis com a proposta da coleção, trazem uma fonte histórica abarcando todo o espaço da página de fundos coloridos diferentes, 
conforme a série. Bastante "inovadora", no sentido de propor o uso escolar da fonte histórica, bem como no que se refere à sua diagramação.

A História Temática não é propriamente uma novidade trazida pelos PCNs, pois já era discutida na França da década de 1970 e, no Brasil, no período denominado de "redemocratização brasileira", algumas discussões sobre ensino e aprendizado histórico já apontavam para eixos temáticos, como o livro O Ensino de História: Revisão Urgente, de Conceição Cabrini (1987). Nele é discutida uma experiência de ensino de História para as $5^{a}$ séries, cujo objetivo seria partir da realidade do aluno com o fim de entender temáticas subjacentes (CABRINI, 1987). Porém, podemos dizer que os PCNs enfatizaram a História Temática, culminando em diversas coleções nesta linha, não apenas, evidentemente, as coleções aqui relacionadas. Ressaltamos que, embora o objetivo dos PCNs e de seus dispositivos de implementação se voltassem para a História Temática, esta não se desenvolveu nos livros didáticos conforme a expectativa.

Flávia Caimi (2009a) entendeu que no PNLD de 2008, por exemplo, estava mais em voga as coleções de História Integrada (em número de sete) ${ }^{15}$ e de História Intercalada (também em número de sete) ${ }^{16}$, do que História Convencional (uma apenas), mas a História Temática era contemplada por quatro coleções. Para a autora, apesar da História Temática emergir como alternativa naquela década (1990), "embalada pelas proposições dos PCN - Área de História (BRASIL, 1997), que contemplam a organização dos conteúdos por eixos temáticos", as coleções

15 "[...] a chamada 'história integrada' que, como indica sua denominação, busca integrar os acontecimentos/conhecimentos históricos de diferentes sociedades, consubstanciados num mesmo tempo cronológico, demonstrando como responderam às demandas colocadas pelo seu tempo e como operaram as transformações necessárias" (CAIMI, 2009a, p. 4).

16 "A história intercalada constitui, pode-se dizer, uma tentativa mal-sucedida de trabalhar com a história integrada, em que conteúdos de história geral, da América e do Brasil são apresentados numa seqüência de capítulos sem que haja relações contextualizadas entre eles; trata-se de uma sucessão de acontecimentos factuais que não ganham significação em temporalidades mais amplas, como as de média duração (conjunturas) e as de longa duração (estruturas). Nesse sentido, pouco difere da história seriada, cuja opção remete a história do Brasil para o terceiro ciclo e a história geral, para o quarto ciclo do ensino fundamental, geralmente desarticulando as temporalidades e espacialidades" (CAIMI, 2009a, p. 7). 
por ela analisadas selecionaram temas ou eixos que não se submetiam à proposta dos PCNs: "Conforme indicado no Guia 2008, a proposta das quatro coleções ditas "temáticas" estrutura-se de acordo com diferentes temas ou eixos, dos quais um ou mais perpassam a coleção e atuam como fio condutor" (CAIMI, 2009a, p. 6) ${ }^{17}$.

Para Maria Auxiliadora Schmidt (2005, p. 206), os eixos temáticos "devem ser mediadores da análise de determinadas questões, inscrevendose na história geral das sociedades", assim "essa mediação permite um ir e vir entre o passado e o presente, entre o local, o regional e o universal, dando condições para a superação da tradicional perspectiva linear da história" (SCHMIDT, 2005 p. 206) ${ }^{18}$. Bittencourt (2004) destaca que no trabalho historiográfico, os pesquisadores já utilizam a História Temática como base: "Cada tema é pesquisado em profundidade, sendo a análise verticalizada, em meio às diversas possibilidades oferecidas, por intermédio de um máximo de documentação a ser selecionada segundo critérios próprios, a qual é interpretada de acordo com determinadas categorias e princípios metodológicos" (BITTENCOURT, 2004, p. 125). Na escola, os eixos "são norteados por pressupostos pedagógicos, tais como faixa etária, nível escolar, tempo pedagógico dedicado à disciplina, entre outros aspectos" (BITTENCOURT, 2004, p. 126). A autora, ainda argumenta que os eixos temáticos "ou temas geradores são indicadores de uma série de temas selecionados de acordo com problemáticas gerais cujos princípios, estabelecidos e limitados pelo público escolar ao qual se destina o conteúdo" (BITTENCOURT, 2004, p. 126).

17 Sobre dados anteriores correspondentes ao período de implementação dos PCNs em relação à História Temática, obtidos pelos Guias dos PNLD, cumpre dizer que de 1992 a 1995, a distribuição e, por consequência, a avaliação dos livros é comprometida pelas limitações orçamentárias e há um recuo na abrangência da distribuição, restringindo-se o atendimento até a $4^{a}$ série do Ensino Fundamental. Só a partir de 1995, de forma gradativa, a volta a universalização da distribuição do livro didático no Ensino Fundamental e em 1996 é iniciado o processo de avaliação pedagógica dos livros inscritos para o PNLD, sendo publicado o primeiro "Guia de Livros Didáticos" de $1^{\text {a }}$ a $4^{\text {a }}$ séries em acordo com critérios previamente discutidos (BRASIL, 201-).

18 Em trabalho vinculado ao Programa de Desenvolvimento Educacional (PDE) do Paraná, orientado pela Profa Dra Marlene Cainelli, Siumara Sagati (200-) em A abordagem temática de conteúdos como metodologia para o ensino de história no Ensino Médio, nos oferece importante discussão sobre a História Temática. Neste texto, a autora faz um apanhado de vários autores que tratam da História Temática e é dele que emprestamos alguns referenciais. 
Flávia Caimi (2009a, p. 5) reuniu elementos que caracterizam a História Temática:

a) a problematização do conhecimento histórico em articulação com a prática social dos estudantes; b) a utilização de diferentes linguagens de ensino e fontes; historiográficas na aprendizagem histórica; c) a ênfase no estabelecimento de relações entre o passado e o tempo presente, de modo a produzir inteligibilidade sobre as experiências sociais e culturais da atualidade, identificando diferenças/semelhanças, rupturas/continuidades; d) 0 investimento na apropriação dos conceitos históricos, reconhecendo o domínio dos conteúdos como meios, não como fins da aprendizagem; e) a preocupação de inserir os estudantes nos procedimentos da pesquisa histórica, dinamizando em sala de aula o estudo de documentos em estado de arquivo familiar e outros tipos de documento; f) a adoção de uma nova dimensão da temporalidade histórica, rompendo com as noções absolutas de linearidade, progresso e evolução, organizando a abordagem dos conteúdos em temas ou eixos temáticos, dentre outras.

Flávia Caimi (2009a) nos apontou vários itens positivos da História Temática, da perspectiva de quem pesquisa o aprendizado histórico, mas existem, também, várias críticas. A experiência do ensino de História por eixos temáticos foi bastante debatida em vários países, sobretudo na França, ainda na década de 1970. Seguindo a abordagem da História Nova, esta experiência europeia favorecia a inclusão de novos objetos, documentos e problemáticas, mas autores como Jacques Le Goff, entenderam que a História Temática terminava por encerrar, no tema, uma cronologia tradicional. Sendo assim, segundo ele, a História permaneceria como narrativa não explicativa ou interpretativa, portanto, substituindo "um saber histórico arcaico por absolutamente nenhum saber" (LE GOFF, 1977, p. 12). Segundo Ernesta Zamboni (1998, p. 35), "o trabalho com eixos temáticos permite também elaborar currículos numa perspectiva mais freireana centrada na realidade social dos grupos a que se destina, pois é no tempo vivido que buscamos o referencial primeiro, concreto, para alcançar a noção de tempo histórico, passível de ser estudado". Entretanto, Zamboni (1998) também avisa sobre determinados riscos: de transformar a História Temática em tradicional ao manter a linearidade, de retirar alguns 
conteúdos considerados tradicionais, mas que precisam ser trabalhados em sala de aula, de saturar os alunos com um único tema tratado em todo ano letivo.

Se a História Temática recaiu no tradicionalismo, isso se manifestou no fato de que os livros organizados, segundo esta abordagem, não prosperaram na época. Já os livros pautados na diversidade de fontes históricas para exploração em sala de aula são usados até os dias atuais. Mas o que veremos nos livros didáticos dos últimos 2-3 anos?

\section{Base Nacional Comum Curricular - História: o passado no futuro}

Um currículo com base nacional demora a ser produzido, mas no entremeio dos PCNs e da BNCC, o livro didático configurou-se forte ponto de discussão pública. A revista Veja, publicada pela Editora Abril, edição n. 2074, de 20 de agosto de 2008, com a reportagem de capa "Você sabe o que estão ensinando a ele?", com o subtítulo "Prontos para o Século XIX", dizia, então, que "Muitos professores e seus compêndios enxergam o mundo de hoje como ele era no tempo dos tílburis" remetendo-se a um ensino ultrapassado, pois ainda incutiria "ideologias anacrônicas e preconceitos esquerdistas nos alunos" (VIEBERG; PEREIRA, 2008, p. 76). Uma imagem em que a foice é uma caneta, e o martelo, um lápis, reforça o argumento, e, novamente a História como disciplina escolar é a mais criticada por ser "marxista", ou mais, precisamente, os professores de História e os livros didáticos de História. A reportagem descreve de forma negativa as aulas de professores de História que estariam preparando seus alunos para viverem no século XIX e não no XXI, "quando marxismo surgiu como ideologia modernizante, capaz não de explicar, mas de mudar o mundo para melhor, acelerando a marcha da história para uma sociedade sem classes" (VIEBERG; PEREIRA, 2008, p. 77). Em tom de denúncia, os repórteres chamam a atenção dos seus leitores com gráficos que apontam que os professores de História e Geografia, ao selecionarem o livro didático 
com o qual trabalharão, utilizam como critério que este deveria: falar a linguagem dos jovens (13\%); mostrar os conteúdos com clareza (44\%) e conscientizar os alunos sobre os problemas do mundo (43\%). Na direção argumentativa da revista, o "marxismo", portanto, seria "ultrapassado" por perspectivar que os alunos questionem o mundo. Em box intitulado "O que diz a cartilha", 3 livros didáticos de Português, 18 livros didáticos de História e 15 livros didáticos de Geografia, têm alguns trechos destacados e comentados para exemplificar este ensino "marxista ultrapassado" adotado pelos professores.

A reportagem evidencia a oposição à ideia de que o ensino deve basear-se na criticidade/problematização da realidade, inclusive trazendo a foto de Paulo Freire. A crítica da revista Veja, direcionava-se mais para os livros didáticos que acreditavam negativar as ideias de empreendedorismo ao destacar, por exemplo, a crise mundial devido às políticas neoliberais, a situação da classe trabalhadora ou movimentos sociais como o ludismo na Revolução Industrial, ou ainda, por, supostamente, exaltar Canudos como sistema comunitário e oposição ao governo. Porém, ao nosso ver, existia um incômodo não evidenciado com a promulgação das leis, no 10.639, de 9 de janeiro de 2003, que estabelecia as diretrizes e bases da Educação nacional para incluir no currículo oficial da rede de ensino a obrigatoriedade da temática "História e Cultura Afro-Brasileira", e a no 11.645, de 10 de março de 2008, que incluiu como obrigatoriedade a "História e Cultura Indígena".

O multiculturalismo, já presente nos PCNs, em especial no tomo dos Temas Transversais como "pluralidade cultural", tornava-se de discussão abrangente, mais cultural do que política, destacando a tolerância em relação às etnias em uma abordagem que tratava das diferentes etnias conforme sua especificidade histórica e cultural. Este ponto, referente ao respeito e compreensão em relação à diversidade étnico-racial foi o mais discutível na disciplina escolar da História, também em relação à BNCC.

Não vamos considerar toda a disputa envolvendo a escrita curricular, provando que o currículo é, como bem disse Ivor Goodson em vários de 
seus textos, território de disputa, apropriação, reelaboração e negociação, porque é permeado por relações de poder (GOODSON, 1991). No nosso entendimento, a primeira versão da BNCC-H de fato rompia com anos de permanências quanto aos conteúdos históricos considerados válidos de serem ensináveis. Pautada na pesquisa acumulada no campo do ensino e aprendizagem histórica - não que a segunda versão também não tenha sido -, a primeira versão invertia totalmente o ponto de partida para o processo do aprendizado histórico. Com a ideia de que a construção do conhecimento histórico deveria atentar-se a vida prática do educando, a primeira versão da BNCC-H considerava as problemáticas circunjacentes aos alunos ou, em outras palavras, a História do Brasil. Desta, pontuava-se, em especial, a História e a Cultura Afro-Brasileira e Indígena, que afinal, representam a História nacional do passado na sua relação com o presente. A Base enfatizava a História do Brasil como espaço político privilegiado da vivência dos estudantes:

\begin{abstract}
Dentro deste recorte intenta-se fazer um alargamento do reconhecimento da presença dos povos indígenas, africanos e afro-brasileiros na história nacional. Já o Ensino Médio, além do destaque anterior, faz um recorte por continentes/áreas culturais, com destaque para o estudo da História da América no $2^{\circ}$ ano (MORENO, 2016, p. 16).
\end{abstract}

De vertentes diferenciadas, a equipe contava como fundamento a noção de que o passado não seria algo estático, amorfo, sem serventia, sendo que são as preocupações do presente que nos fazem voltar a ele de forma racionalizada. Este enfoque implicava em um estudo acumulado de 20-25 anos em torno do ensino e aprendizagem histórica, difícil de retomar neste texto. Flávia Caimi (2009b) resume, considerando duas vertentes principais deste campo, com mais convergência do que propriamente divergência: os estudos cognitivos e a Educação Histórica. A primeira, mais voltada para o campo da Pedagogia, para autores como Jean Piaget, Vygotsky e Bruner, cujo parâmetro é perceber os caminhos para a construção do conhecimento, e a segunda, tendo como referencial a epistemologia da História, com autores como Jörn Rüsen, Peter Lee, Isabel Barca e Maria Auxiliadora Schmidt, entre outros, que analisa o produto da 
aprendizagem, buscando entender como os agentes escolares entendem a História (CAIMI, 2009b, p. 70-71). Tanto uma vertente como a outra, entendem que devemos apreender os agentes escolares como sujeitos, importando aquilo que pensam; por isso mesmo, a realidade destes sujeitos deve ser o ponto de partida para entender a realidade histórica circundante, considerando o ensino e aprendizagem histórica mediante conceitos, operações, estratégias próprias.

A BNCC-H, primeira versão, abarca estas duas vertentes em sua interdependência, embora cometa o equívoco de não mencionar seus fundamentos teórico-metodológicos. Os currículos da passagem da década de 1980-1990, marcavam seu referencial como sendo histórico-críticos e os PCNs realizam a trajetória histórica dos currículos, inclusive criticando os currículos anteriores, de modo a legitimarem-se como currículos renovados, construtivistas e pautados na Nova História.

A abordagem da primeira versão da Base pode ser entendida de duas formas: círculos concêntricos e/ou eixos temáticos, além de problematizar a realidade próxima do aluno com a meta de se estender esta compreensão para além da localidade. Na BNCC-H, na primeira versão, os círculos concêntricos são manifestos na organização dos conteúdos (conceitos substantivos): Na BNCC, a História Temática se apresenta da seguinte forma: ENSINO FUNDAMENTAL: 10 ANO - Sujeitos e Grupos Sociais; $2^{\circ}$ ANO - Grupos Sociais e Comunidades; 30 ANO - Comunidades e outros lugares de vivências; 40 ANO - Lugares de vivências e relações sociais; $5^{\circ}$ ANO - Mundos brasileiros; 60 ANO - Representações, sentidos e significados do tempo histórico; 70 ANO - Processos e Sujeitos; $8^{\circ}$ ANO - Análise de processos históricos; 90 ANO - Análise de processos históricos; ENSINO MÉDIO: $1^{\circ}$ ANO - Mundos ameríndios, africanos e afro-brasileiros; 20 ANO Mundos americanos; 30 ANO - Mundos europeus e asiáticos (BRASIL, 2015). Em síntese, a História começa com a ênfase no Eu (História Pessoal) e vai seguindo a linha histórica: Família, Escola, Bairro, Cidade, Estado, Brasil, Américas, Geral. Quanto aos conceitos estruturais dos eixos temáticos, que deveriam ser utilizados do início do Ensino Fundamental ao 
último ano do Ensino Médio, a BNCC-H primeira versão recomenda: procedimentos de pesquisa; representações do tempo; categorias, noções e conceitos; e dimensões político cidadãs.

Embutida na lógica dos círculos concêntricos, a noção de que o processo de aprendizagem ocorre quando se parte do mais "próximo" ao mais "distante", da "parte" para o "todo" ou do "concreto" para o "abstrato", o que nos reporta às conclusões apropositadas de Heloísa Dupas Penteado (1994): a aprendizagem de História se faz em um movimento do todo para as partes e das partes para o todo; o concreto para o aluno é aquilo que ele acredita existir, e não, simplesmente, o que ocorre e é perceptível aos órgãos dos sentidos, e, o "próximo" depende do significado e importância atribuídos pelo aluno ao acontecimento que faz, ou não, parte de sua realidade. A autora lembrou que pessoas ou grupos podem conviver em proximidade espaço-temporal, mas estarem muito distantes socialmente; os acontecimentos veiculados pela mídia podem ser considerados mais próximos para o aluno do que o que acontece em seu bairro, e a escola, tomada supostamente como algo simples a ser estudado, em geral representa, na fase inicial da escolaridade, uma realidade mais complexa, desconhecida e ameaçadora ao educando do que, por exemplo, o município. Os círculos concêntricos implicam em ampliação do grau de complexidade, porém, às vezes, o mais próximo, dependendo da idade do aluno, pode ser mais complexo que o mais longínquo. Por exemplo, a realidade de um bairro violento pode ser mais complexa de ser entendida do que a realidade da China, distante, talvez exótica e encantadora.

Podemos criticar a validade destes círculos concêntricos, mas dependendo da forma didático-pedagógico de como é explorado na prática, permite-se uma aprendizagem histórica satisfatória, por parte da realidade do educando. Aliás, afirmativa que se aplica se consideramos quaisquer proposta curricular e metodologia de ensino, o que será reafirmado em outro parágrafo deste texto. Na BNCC-H, estes círculos podem ocorrer no interior dos eixos temáticos, embora não haja, como mencionamos, uma explicação embasada, teoricamente, no texto curricular. Por exemplo: a 
respeito da realidade atual do aluno, a situação política brasileira pode nos fazer tratar da problemática da democracia, recorrendo às relações possíveis entre o "aqui" e o "em outros lugares", bem como o "agora" e "em outras temporalidades", inclusive retomando a democracia na Antiguidade. Ao tratar da questão religiosa na atualidade, o aumento das igrejas evangélicas, por exemplo, podemos tratar da intolerância religiosa e estender o assunto para a Idade Média, o poder da Igreja Católica, a Reforma e Contrarreforma. Lembrando que não há como estudar a História e Cultura indígena, se não retomarmos o contexto da formação das Nações europeias, das grandes navegações, do mercantilismo. Da mesma forma, não há como falar da escravidão, se não tivermos em mente a História da África, da diferença entre o sistema escravista empreendido pelos portugueses na colônia e das práticas escravistas em territórios africanos, etc. Todo tema histórico pode ser explorado nesta perspectiva de se dar início com uma problemática que interfere na vida prática do educando, para o estudo de sociedades ou grupos do passado ou de outras localidades no presente. Desta forma, os conteúdos históricos propostos seriam o "centro", ou "dentro", de onde se segue ampliando a temática, mas o movimento pode ser, também, de "ida e volta", ou seja, podemos começar da "parte" e chegar ao "todo", e vice-versa.

Esta organização curricular seria interessante do ponto de vista didático-pedagógico, em especial, do ensino e aprendizagem histórica. Porém, como esta organização de desdobraria no livro didático de História? Provavelmente, as editoras teriam que investir em novas coleções, totalmente reformuladas, não apenas por considerarmos a cronologia não linear. Os eixos temáticos com círculos concêntricos mobilizariam habilidades complexas dos autores e das editoras, lembrando que as coleções baseadas em História Temática dos anos 1995-2005, não tiveram grande fôlego, o que seria, atualmente, correr um grande risco de investimento. Além do mais, pesquisas como de Daniel Medeiros (2005), demonstram que estes livros didáticos "renovados" não obtiveram muito sucesso junto aos professores naquele período, pois estes preferem obras 
mais "tradicionais", ou seja, de cronologia linear e conteúdo eurocêntrico. Teriam se transformado as demandas e/ou preferências dos professores? Editoras, autores e professores estariam dispostos a romper com 0 "tradicional" em termos de cronologia e conteúdos?

Muitas críticas foram legítimas. De fato, esta primeira versão da Base, uma versão preliminar, contava com vários problemas, entre eles, o de não explicitar seus fundamentos teóricos metodológicos, nem em relação ao campo didático-pedagógico, nem quanto à historiografia.

A BNCC contou com três versões, mediante várias polêmicas envolvendo professores e associações ligados às universidades, mas, também, jornalistas, blogueiros, comentaristas e políticos. Os sujeitos vinculados ao setor acadêmico priorizavam a "retórica da perda", ou seja, não conseguiram entender o enfoque proposto ao considerarem que a primeira versão da Base retirava conteúdos de História Antiga e História Medieval (PINTO JUNIOR; BUENO; GUIMARÃES, 2016).

Enquanto que na História Pública, principalmente nos jornais, se destacava a crítica ao que consideravam como ênfase nas questões étnicoraciais. Na matéria História sem Tempo, publicada pela Gazeta do Povo (08/12/2015), os autores Demétrio Magnoli e Elaine Senise Barbosa (2015b) apontam que "emerge uma sociologia do multiculturalismo destinada a apagar a lousa na qual gerações de professores ensinaram o processo histórico que conduziu à formação das modernas sociedades ocidentais, fundadas no princípio da igualdade dos indivíduos perante a lei". É como se o fato de tratar da História brasileira, então inseparável da compreensão da História e Culturas africana, afrodescendente e indígena, pudesse apagar seu vínculo com a História geral, ocidental.

Em Ensino de História no Brasil em xeque, por Rosana Félix, na Gazeta do Povo (18/12/2015), Maria Auxiliadora Schmidt e Márcia Elisa Teté Ramos, embora diziam que seria ainda cedo para analisar a primeira versão da Base, terminavam, de certa forma, defendendo-a, considerando o rompimento com a História eurocentrada. Ao falar da função social da História, Ramos destacava a compreensão em relação ao Outro (cultura, 
geração, religião, etnia, etc.). Esta afirmação foi criticada em Proposta do MEC para ensino de história mata a temporalidade, na Folha de S. Paulo por Demétrio Magnoli e Elaine Senise Barbosa (2015a). Segundo estes autores, Márcia Ramos "defendeu a proposta do MEC recorrendo a uma alegação orweliana de aparência banal" e, mais à frente, chamavam esta defesa de "lulopetista". Em outras palavras, os autores entendem que partir da História do Brasil, das histórias e culturas que, até então, foram excluídas/marginalizadas, mas que compõem o povo brasileiro, seria um posicionamento partidário e que apenas invertia a relação de poderes, como em Revolução dos Bichos de George Orwell ${ }^{19}$.

Rodeada de polêmicas em múltiplas instâncias, a primeira versão deu lugar a uma segunda - que não trataremos no momento -, e uma versão final. Nesta, rompe-se com a concepção de círculos concêntricos e História Temática. Os conteúdos voltam a serem dispostos como foram no decorrer da História do Ensino de História. Nos anos iniciais, pressupõe-se a ordem da História: Pessoal, Família, Bairro, Cidade e Estado. Porém, no sexto ano, estipula-se a História Antiga, no sétimo, História Medieval e assim por diante. Não é difícil observar que existe uma lacuna se nos basearmos nos círculos concêntricos. Mas a terceira versão da Base nos abre possibilidades diversas, se lembrarmos do que já mencionamos aqui: dependerá da forma como o professor desenvolve o processo de ensino de História.

Pontos que abrem possibilidades: da mesma forma que podemos partir da História do Brasil para estender para a História Geral, podemos fazer o contrário. Assim, por exemplo, a História Antiga pode nos facilitar o entendimento/comparação/problematização da democracia brasileira. Ao tratar no sétimo ano da Idade Média, algumas temáticas são introduzidas para além dos fenômenos históricos europeus: "No 70 ano, as conexões entre Europa, América e África são ampliadas. São debatidos aspectos políticos, sociais, econômicos e culturais ocorridos a partir do final do século XV até o final do século XVIII" (BRASIL, BNCC, 2016, p. 368).

19 Outras críticas: Funari (2015), Righetti (2015) e Vainfas (2015). 
Nesta versão, existe a possibilidade de "valorização da história da África e das culturas afro-brasileira e indígena (Lei no 10.639/200344 e Lei no 11.645/200845)", que ganharia "realce não apenas em razão do tema da escravidão, mas, especialmente, por se levar em conta a história e os saberes produzidos por essas populações" e "ao mesmo tempo, são objetos de conhecimento os processos de inclusão/exclusão dessas populações nas recém-formadas nações do Brasil e da América ao longo dos séculos XIX e XX" (BRASIL, BNCC, 2016, p. 367-368). O componente (EF08HI20), por exemplo, diz que se deve "Identificar e relacionar aspectos das estruturas sociais da atualidade com os legados da escravidão no Brasil e discutir a importância de ações afirmativas" (BRASIL, BNCC, 2016, p. 377).

Se recomenda o uso escolar do documento histórico (BRASIL, BNCC, p. 348, 369) e a introdução da questão da multiperspectividade, considerando como exemplo as diferentes versões sobre a Guerra do Paraguai (BRASIL, BNCC, p. 369). Indica-se as chamadas competências ou habilidades - o mesmo jargão dos PCNs - para lidar com a interpretação das fontes: identificação, comparação, contextualização e análise (BRASIL, BNCC, p. 348-350).

Pontos negativos: A terceira versão da BNCC-H enfatiza a cronologia tradicional, o que "implica o uso de uma forma de representação, a cronológica, constituída por meio de uma seleção de eventos históricos consolidados na cultura historiográfica" (BRASIL, BNCC, p. 367). É clara a opção dos eventos que "permitem a constituição de uma visão global da história, palco das relações entre o Brasil, a Europa, o restante da América, a África e a Ásia ao longo dos séculos" (BRASIL, BNCC, p. 367), ou seja, não se começa da parte, da História do Brasil, mas de uma História Global, do todo.

Apesar de termos estas orientações supramencionadas que correspondem, de certa maneira, ao que se discute nas pesquisas em ensino e aprendizagem histórica, quando os conteúdos se transformam em códigos referentes aos componentes curriculares, a BNCC-H torna-se técnica, como o componente (EF08HIO2): "Identificar as particularidades 
político-sociais da Inglaterra do século XVII e analisar os desdobramentos posteriores à Revolução Gloriosa" (BRASIL, BNCC, 2016, p. 375). Ou então, é dúbia em seus posicionamentos como no componente (EF08HI14): "Discutir a noção da tutela dos grupos indígenas e a participação dos negros na sociedade brasileira do final do período colonial, identificando permanências na forma de preconceitos, estereótipos e violências sobre as populações indígenas e negras no Brasil e nas Américas" (BRASIL, BNCC, 2016 , p. 374). Neste, embora haja intenção de problematizar, se utiliza o vocábulo "tutela" e se vermos o objeto de conhecimento, este seria: "A tutela da população indígena, a escravidão dos negros e a tutela dos egressos da escravidão". O que seria esta tutela no contexto das lutas e resistências, já que em qualquer dicionário o significado é "proteção exercida em relação a alguém ou a algo mais frágil"?, mesma coisa em relação ao componente (EF09HI20): "Discutir os processos de resistência e as propostas de reorganização da sociedade brasileira durante a ditadura civil-militar" (BRASIL, BNCC-H, p. 380). Estes "processos de resistências" deixam vagos os debates em relação ao regime antidemocrático.

Podemos entrever que o livro didático deverá seguir componente por componente da BNCC. Já no edital do PNLD 2019, séries iniciais, o critério de avaliação deve ter como referência a BNCC, prezando o "desenvolvimento das competências e habilidades envolvidas no processo de aprendizagem nos anos inicias do ensino fundamental, conforme definidas no Anexo III-A, que corresponde à versão da Base Nacional Comum Curricular (BNCC) enviada ao Conselho Nacional de Educação pelo MEC em abril de 2017" (BRASIL, 2017, p. 27) ${ }^{20}$. No Guia do PNLD 2019 de História, lê-se que a avaliação apresenta algumas mudanças, sendo que "A mais substancial delas é a incorporação e o tratamento dado pelas obras didáticas às competências, objetos de conhecimento e habilidades, preconizados na Base Nacional Comum Curricular (BNCC) - terceira versão através dos quais se pretende materializar e garantir a formação integral para a cidadania" (BRASIL, 2018). Ou seja, o livro didático de História teria

\footnotetext{
${ }^{20}$ Lembrando que o edital é publicado de um a dois anos antes do ano de vigência.
} 
que, neste caso do exemplo acima, falar da tutela em relação à indígenas e ex-escravizados, e preencher as lacunas do que diz ser "resistências" no período da Ditadura Civil-Militar brasileira.

A BNCC e os livros didáticos que devem segui-la - segundo os editais -, trazem os códigos, e seus respectivos componentes, como conteúdos a serem desenvolvidos em sala de aula, sem que haja discussões sobre o porquê de cada um deles. Tal concepção nos faz lembrar do tecnicismo como tendência dos anos 1970, às vezes inspirada em práticas pedagógicas behavioristas, pois controladas e dirigidas pelo professor, com atividades mecânicas inseridas numa proposta educacional rígida e passível de ser, totalmente, programada em detalhes. O professor passa a ser um mero especialista na aplicação de currículos e livros didáticos, e sua criatividade fica dentro dos limites possíveis e estreitos da técnica utilizada ${ }^{21}$.

\section{Considerações Finais}

Os livros didáticos precisam ser vistos em uma rede de significação. Não são apenas mercadorias a serem compradas pelo Estado e repassadas aos alunos, ou mesmo produto cultural ou material didático; não devem se orientar apenas pela atualização historiográfica ou vertente didáticopedagógica, bem como não são regrados, tão somente, pelas estratégias de diagramação. Também não são apenas tradutores curriculares, mas, neste texto, procuramos relacionar currículo didático e livro didático de História em sua discussão na História Pública, principalmente midiática.

Tomamos três momentos: 1) a dos currículos da transição da década de 1980-1990, produzidos em cada Estado, correspondendo à uma vertente que se expressa em alguns livros didáticos, voltada para a Pedagogia histórico-crítica e historiografia marxista, que encontrou terreno propício no pós-Ditadura. Estes currículos e livros apregoavam a necessidade de tratar de "toda a História" e de politizar os conteúdos históricos. Rechaçavam-se livros didáticos e currículos ligados aos governos anteriores, tidos como

${ }^{21}$ Ver mais em: Libâneo (1982), Saviani (2008) e Silva (2016). 
suporte de uma ideologia de direita. Permanece uma visão cronológica linear e eurocêntrica, mas pautada ora por temáticas economicistas (modo de produção), ora políticas (exploração, luta de classes, movimentos sociais); 2) os PCNs de História, com base pedagógica construtivista e historiografia de referencial na Nova História, apesar de tentarem se distanciar de alguns princípios inseridos no tomo introdutório, trazem uma noção culturalista (multiculturalismo) e despolitizadora (não se fala mais de injustiça social, desigualdade social) em alguns momentos, mas avançada quando propõe o uso escolar de fontes históricas e História Temática, resultando em livros didáticos com a mesma abordagem. Embora a História Temática não tenha vingado, os livros didáticos de História começaram a ter como prática a inserção de interpretação de fontes históricas. A mídia, provavelmente devido às leis que tornaram obrigatório, na Educação Básica, o tratamento das Histórias e Culturas africanas, afro-brasileiras e indígenas, aqui representada pela revista Veja, passou a ver os livros didáticos como portadores de uma ideologia de esquerda e 3) a BNCC-História que, em três versões, vai de uma abordagem que mescla História Temática e círculos concêntricos para tratar das problemáticas do presente, desta forma, partindo da História do Brasil, à História cronológica linear, quadripartite e eurocêntrica, continua indicando a interpretação de fontes históricas em sala de aula e traz (poucos) componente curriculares problematizadores (possibilidades), porém tende a tratar a História como conjunto de competências, gerando uma abordagem tecnicista (limites). Ainda: alguns temas são vistos de forma vaga e questionável, com a tutela dos indígenas e escravizados e as resistências na Ditadura Civil-Militar, exemplos dados acima.

Os livros didáticos de História que agora virão, talvez tragam mais limites que possibilidades. Dizemos isso pelo próprio contexto histórico vivenciado no mundo e, especificamente, no Brasil, onde é obscura a função do PNLD em um futuro próximo, devido à desqualificação da Educação institucionalizada, engendrada pelos discursos políticos, midiáticos e mesmo do senso comum, bem repetidos nas várias instâncias públicas. A vivência 
cotidiana faz ver que na era da "pós-verdade", conhecimentos históricos paralelos, completamente destoantes da História como ciência, são defendidos como óbvios. Um suposto "revisionismo" procura usar o passado como parâmetro para o indefensável em uma sociedade democrática e pautada na ética, nos direitos humanos. A mídia ainda não se aquietou na denúncia quanto aos "erros" dos livros didáticos, principalmente, de História, e não sabemos se tais denúncias podem gerar intervenções na elaboração dos materiais didáticos, de modo a impor o que considera "revisionismos" históricos 22 .

Se permanece a História Tradicional e baseada pelo factual, eurocentrismo e desenvolvimento de "competências", mais fácil abrir as portas para opiniões acríticas, conservadoras, não fundamentadas no livrepensar, na autonomia na construção do conhecimento histórico. Por isso mesmo, como professores de História devemos enfrentar o desafio de tratar o próprio livro didático como fonte histórica e usá-lo da melhor forma que pudermos, inserindo problematizações nas suas margens, pois o livro didático é o que pretendemos fazer com ele. Nunca é literalmente praticado, mas reelaborado e transgredido. A História Pública precisa ser vista em sua complexidade, para que saibamos o que circula, a fim de entendermos como atuar nela diretamente, seja pelo currículo ou pelo livro didático, entre outros. Talvez a História Temática, então (re)elaborada segundo a experiência e pesquisa acumuladas quanto ao ensino e aprendizado de História, poderia ser um caminho para fazer efeito na História Pública, de modo a empreender uma sociedade melhor, pautada na compreensão, respeito e enriquecimento da identidade por intermédio da alteridade.

\section{Referências}

ALBIERI, Sara. Apontamentos. In: ALMEIDA, Juniele Rabêlo; ROVAI, Marta Gouveia de Oliveira (org.). Introdução à História Pública. São Paulo: Letra e Voz. 2011. p. 19-30.

\footnotetext{
22 Textos que criticam o livro didático: Constantino (2015), Azevedo (2007b, 2017). Ainda sobre revisionismo: Azevedo (2009), Constantino (2017), Ulhôa (2001) e Villa (2014).
} 
ALMEIDA, Juniele Rabêlo; ROVAI, Marta Gouveia de Oliveira (org.). Introdução à História Pública. São Paulo: Letra e Voz. 2011.

AZEVEDO, Reinaldo. Esquerdopatia nas escolas, a nota do MEC, a educação no pântano. Revista Veja, São Paulo, 18 set. 2007a.

AZEVEDO, Reinaldo. Livro didático faz a apologia do erro: exponho a essência da picaretagem teórica e da malvadeza dessa gente. Revista Veja, São Paulo, 20 fev. 2017.

AZEVEDO, Reinaldo. Maria Victoria e Comparato usam lei da ditadura para contestar ditabranda. Revista Veja, São Paulo, 14 mar. 2009.

AZEVEDO, Reinaldo. Mistificação 1: o petismo chega ao livro didático. Agora sem disfarca. Revista Veja, São Paulo, 2 out. 2007b.

AZEVEDO, Reinaldo. Nossas crianças estão entregues à sanha esquerdopata. Revista Veja, São Paulo, 18 set. 2007c.

AZEVEDO, Reinaldo. Panfleto didático 2: o MEC acorda tarde. Revista Veja, São Paulo, 20 set. 2007d.

AZEVEDO, Reinaldo. Uma entrevista com Ali Kamel. Revista Veja, São Paulo, 21 set. 2007 e.

AZEVEDO, Reinaldo. Uma nova geração de energúmenos. Revista Veja, São Paulo, 19 set. $2007 f$.

BERGMANN, Klaus. A História na reflexão didática. Revista Brasileira de História, São Paulo, v. 9, n. 19, p. 29-42, set./fev. 1990.

BITTENCOURT, Circe Maria Fernandes. Capitalismo e cidadania nas atuais propostas curriculares de História. In: BITTENCOURT, Circe Maria Fernandes (org.). O saber histórico em sala de aula. São Paulo: Contexto, 1997. p. 1127.

BITTENCOURT, Circe Maria Fernandes. Ensino de História: fundamentos e métodos. São Paulo: Cortez, 2004.

BRASIL. Secretaria de Educação Fundamental. Parâmetros curriculares nacionais: história. Brasília: MEC, SEF, 1997.

BRASIL, Base Nacional Comum Curricular. Ministério da Educação. 2015. Disponível em http://docs.wixstatic.com/ugd/d8d064_86ba8d7ba16f43a091abbd2b7e6983 e6.pdf Acesso em: 15 jan. 2019. 
BRASIL, Base Nacional Comum Curricular. Ministério da Educação. 2015. Disponível em http://www.observatoriodoensinomedio.ufpr.br/wpcontent/uploads/2017/04/BNCC-Documento-Final.pdf Acesso 15 jan. 2019.

BRASIL. Ministério da Educação. Fundo Nacional de Desenvolvimento da Educação. Histórico. [201-]. Disponível em:

https://www.fnde.gov.br/programas/programas-do-livro/livrodidatico/historico Acesso em: 15 jan. 2019.

BRASIL. Ministério da Educação. Secretaria de Educação Básica. Fundo Nacional de Desenvolvimento da Educação. Edital de convocação 01/2017: CGPLI. Brasília: MEC, 2017. Disponível em:

http://portal.mec.gov.br/docman/agosto-2017-pdf/70041-edital-pnld-2019pdf/file. Acesso em: 10 nov. 2018.

BRASIL. Ministério da Educação. Secretária de Educação Básica. Fundo Nacional de Desenvolvimento da Educação. PNLD 2019: história: guia de livros didáticos. Brasília: MEC, 2018. Disponível em: https://s3.us-east2.amazonaws.com/plataforma-pnld/guias/Guia_PNLD_2019_historia.pdf. Acesso em: 10 nov. 2018.

BRASIL. Ministério da Educação. Secretaria de Educação Fundamental. Parâmetros curriculares nacionais: história. Brasília: MEC: SEF, 1998.

CABRINI, Conceição. O ensino de História: revisão urgente. São Paulo: Brasiliense, 1987.

CAIMI, Flávia. História convencional, integrada, temática: uma opção necessária ou um falso debate? In: SIMPÓSIO NACIONAL DE HISTÓRIA, 25., 2009, Fortaleza. Anais [...]. São Paulo: ANPUH, 2009a.

CAIMI, Flávia. História escolar e memória coletiva: como se ensina? Como se aprende? In: ROCHA, Helenice; MAGALHÃES, Marcelo; GONTIJO, Rebeca (org.). A escrita da história escolar: memória e historiografia. Rio de Janeiro: Editora FGV, 2009b. p. 65-79.

CHEVALLARD, Yves. La transposición didáctica: del saber sábio al saber enseñado. Buenos Aires: Aique, 1991.

CONSTANTINO, Rodrigo. Escola sem partido já! In: Escola Sem Partido. [S. l.], 6 mar. 2015. Disponível em: http://www.escolasempartido.org/artigostop/536-escola-sem-partido-ja. Acesso em: 12 nov. 2018.

CONSTANTINO, Rodrigo. O contexto em 1964. Gazeta do Povo, Curitiba, 1 abr. 2017.

DOMINGUES, Joelza Esther. História em documento: imagem e texto. São Paulo: FTD, 2001. v. 5-8. 
FAGUNDES, Bruno Flávio Lontra. O que é, como e por que história pública? Algumas considerações sobre indefinições. In: CONGRESSO

INTERNACIONAL DE HISTÓRIA, 8., 2017, Maringá. Anais [...]. Maringá: UEM, 2017. Disponível em:

http://www.cih.uem.br/anais/2017/trabalhos/3426.pdf. Acesso em: 14 jan. 2019.

FARIA, Ana Lúcia Goulart de. Ideologia no livro didático. 6. ed. São Paulo: Cortez: Autores Associados, 1987.

FÉLIX, Rosana. Ensino de História no Brasil em xeque. Gazeta do Povo, Curitiba, 18 dez. 2015.

FOUCAULT, Michel. Vigiar e punir. Rio de Janeiro: Vozes, 2000.

FUNARI, Pedro Paulo. Mudanças no ensino de história são prejudiciais, diz professor da Unicamp. Folha de S. Paulo, São Paulo, 23 out. 2015.

GOODSON, Ivor Frederick. La construcción social del curriculum: posibilidades y ámbitos de investigación de la historia del curriculum. Revista de Educación, Madrid, n. 295, p. 7-37, 1991.

HÖFLING, Eloisa de Mattos. O livro didático em Estudos Sociais. Campinas: Editora Unicamp, 1986.

KAMEL, Ali. O que ensinam às nossas crianças. $O$ Globo, Rio de Janeiro, 18 set. 2007.

LAUTIER, Nicole. Os saberes históricos em situação escolar: circulação, transformação e adaptação. Educação \& Realidade, Porto Alegre, v. 36, n. 1, p. 39-58, jan./abr. 2011.

LE GOFF, J. et al. A nova história. Rio de Janeiro: Edições 70, 1977.

LIBÂNEO, José Carlos. Saber, saber ser, saber fazer: o conteúdo do fazer pedagógico. Revista da $A N D E$, Rio de Janeiro, v. 1, 1982.

LIDDINGTON, Jill. What Is Public History? Publics and Their Pasts, Meanings and Practices. Oral History, v. 30, n. 1, Women's Narratives of Resistance, p. 83-93, 2002.

LIMA, André de. Carta Capital dedica capa e oito páginas ao PNLD. In: Abrelivros. São Paulo, 1 out. 2017. Disponível em: http://www.abrelivros.org.br/home/index.php/noticias/2235-carta-capitaldedica-capa-e-oito-paginas-ao-pnld. Acesso em: 11 nov. 2018.

MACEDO, José Rivair; OLIVEIRA, Marley W. Brasil: uma história em construção. São Paulo: Editora do Brasil, 1996. v. 2. 
MAGNOLI, Demétrio; BARBOSA, Elaine Senise. História sem tempo. Gazeta do Povo, Curitiba, 8 nov. 2015a.

MAGNOLI, Demétrio; BARBOSA, Elaine Senise. Proposta do MEC para ensino de história mata a temporalidade. Folha de S. Paulo, São Paulo, 8 dez. 2015b.

MALERBA, Jurandir. Acadêmicos na berlinda ou como cada um escreve a História? Uma reflexão sobre o embate entre historiadores acadêmicos e não acadêmicos no Brasil à luz dos debates sobre Public History. História da Historiografia, Ouro Preto, v. 15, p. 27-50, ago. 2014.

MARTINS, Maria do Carmo. A CENP e a criação do currículo de História: a descontinuidade de um projeto educacional. Revista Brasileira de História, São Paulo, v. 18, n. 36, p. 36-60, 1998.

MEDEIROS, Daniel Hortêncio. A formação da consciência histórica como objetivo do ensino de História no Ensino Médio: o lugar do material didático. 2005. 208 f. Tese (Doutorado em Educação) - Universidade Federal do Paraná, Curitiba, 2005.

MONTELLATO, Andrea Rodrigues Dias; CABRINI, Conceição; CATELLI JUNIOR, Roberto. História temática: diversidade cultural e conflitos. São Paulo: Scipione, 2000.

MONTELLATO, Andrea Rodrigues Dias; CABRINI, Conceição; CATELLI JUNIOR, Roberto. História temática: tempos e culturas. São Paulo: Scipione, 2000.

MONTELLATO, Andrea Rodrigues Dias; CABRINI, Conceição; CATELLI JUNIOR, Roberto. História temática: terra e propriedade. São Paulo: Scipione, 2000.

MONTELLATO, Andrea Rodrigues Dias; CABRINI, Conceição; CATELLI JUNIOR, Roberto. História temática: o mundo dos cidadãos. São Paulo: Scipione, 2000.

MORENO, Jean Carlos. História na Base Nacional Comum Curricular: déjà vu e novos dilemas no século XXI. História \& Ensino, Londrina, v. 22, n. 1, p. 7-27, jan./jun. 2016.

MUNAKATA, Kazumi. História que os livros didáticos contam depois que acabou a ditadura no Brasil. In: FREITAS, Marcos Cezar de (org.). Historiografia brasileira em perspectiva. São Paulo: Contexto, 1998. p. 271296.

NADAI, Elza. O ensino de história no Brasil: trajetória e perspectivas. Revista Brasileira de História, São Paulo, v. 13, n. 25/26, p. 143-162, set./ago. 1993. 
NADAI, Elza; NEVES, Joana. História do Brasil: da Colônia à República. São Paulo: Saraiva, 1991a.

NADAI, Elza; NEVES, Joana. História geral: antiga e medieval. 5. ed. São Paulo: Saraiva, 1991b.

NADAI, Elza; NEVES, Joana. História geral: moderna e contemporânea. 8. ed. São Paulo: Saraiva, 1991c.

NIKITIUK, Sônia. Repensando o ensino de história. São Paulo: Cortez, 1996.

NOSELLA, Maria de Lourdes Chagas Deiró. As belas mentiras: a ideologia subjacente aos textos didáticos. 8. ed. São Paulo: Moraes, 1981.

PARANÁ. Secretaria de Estado da Educação. Superintendência de Educação. Departamento de Ensino de Primeiro Grau. Currículo básico para a escola pública do Estado do Paraná. Curitiba: SEED, 1990.

PENTEADO, Heloísa Dupas. Metodologia do ensino de História e Geografia. São Paulo: Cortez, 1994.

PINSKY, Jaime (org.). O ensino de história e a criação do fato. 5. ed. São Paulo: Contexto, 1992.

PINTO JUNIOR, Arnaldo; BUENO, João Batista Gonçalves; GUIMARÃES, Maria de Fátima. A BNCC em pauta: quando nós vamos estudar nossa história? In: MOLINA, Ana Heloísa; FERREIRA, Carlos Augusto Lima (org.). Entre textos e contextos: caminhos do ensino de história. Curitiba: Editora CRV, 2016. p. 61-82.

PROST, Antoine. Doze lições de história. Tradução Guilherme João de Freitas Teixeira. Belo Horizonte: Autêntica, 2008.

RAMOS, Márcia Elisa Teté. O ensino de história na revista Nova Escola (1986-2002): cultura midiática, currículo e ação docente. Curitiba: CRV, 2015.

RICCI, Claudia Sapag. Quando os discursos não se encontram: imaginário do professor de história e a reforma curricular dos anos 80 em São Paulo. Revista Brasileira de História, São Paulo, v. 18, n. 36, p. 61-88, 1998.

RIGHETTI, Sabine. Proposta de ministério que altera ensino de história causa reações. Folha de S. Paulo, São Paulo, 22 nov. 2015.

ROSENZWEIG Roy; THELEN, David. The Presence of the Past. Popular Uses of History in American Life. New York: Columbia University Press, 1998. 
RÜSEN, Jörn. Didática da História: passado, presente e perspectivas a partir do caso alemão. In: SCHMIDT, Maria Auxiliadora; BARCA, Isabel; MARTINS, Estevão de Rezende (org.). Jörn Rüsen e o ensino de História. Curitiba: Editora UFPR, 2010a. p. 23-40.

RÜSEN, Jörn. Aprendizado histórico. In: SCHMIDT, Maria Auxiliadora; BARCA, Isabel; MARTINS, Estevão de Rezende (org.). Jörn Rüsen e o ensino de História. Curitiba: Editora UFPR, 2010b. p. 41-50.

RÜSEN, Jörn. Narrativa histórica: fundamentos, tipos, razão. In: SCHMIDT, Maria Auxiliadora; BARCA, Isabel; MARTINS, Estevão de Rezende (org.). Jörn Rüsen e o ensino de História. Curitiba: Editora UFPR, 2010c. p. 93-108.

SAGATI, Siumara. A abordagem temática de conteúdos como metodologia para o ensino de história no Ensino Médio. [200-]. Disponível em: http://www.gestaoescolar.diaadia.pr.gov.br/arquivos/File/producoes_pde/ar tigo_siumara_sagati.pdf. Acesso em: 12 out. 2018.

SALLES, André Mendes. A guerra do Paraguai nas edições do livro didático História do Brasil: da colônia à república, das autoras Elza Nadai e Joana Neves. Educação Básica Revista, Sorocaba, v. 3, n. 2, p. 291-311, 2017.

SANTHIAGO, Ricardo. Duas palavras, muitos significados: alguns comentários sobre a história pública no Brasil. In: MAUAD, Ana Maria; ALMEIDA, Juniele Rabêlo; SANTHIAGO, Ricardo (org.). História pública no Brasil: sentidos e itinerários. São Paulo: Letra e Voz, 2016. p. 23-35.

SAVIANI, Dermeval. A pedagogia no Brasil: história e teoria. Campinas: Autores Associados, 2008.

SCHMIDT, Maria Auxiliadora. História: construindo a relação conteúdo método no ensino de História no Ensino Médio. In: KUENZER, Acácia Zeneida. Ensino Médio: construindo uma proposta para os que vivem do trabalho. São Paulo: Cortez, 2005. p. 203-230

SILVA, Andréa Villela Mafra da. A pedagogia tecnicista e a organização do sistema de ensino brasileiro. Revista HISTEDBR On-line, Campinas, v. 16, n. 70, p. 197-209, dez. 2016.

SOFFIATI, Arthur. A ausência da natureza nos livros didáticos de história. Revista Brasileira de História, São Paulo, v. 9, n. 19, p. 43-56, set./fev. 1990.

ULHÔA, Raquel. Historiador diz que série busca visão independente. Folha de S. Paulo, São Paulo, 8 jan. 2001.

UMBELINO, Giseli Origuela. A Nova História Crítica de Mario Schmidt: um diálogo entre imprensa, academia e público consumidor sobre o livro 
didático e o ensino. Revista Trilhas da História, Três Lagoas, v. 7, n. 13, p. 23-43, jul./dez. 2017.

VAINFAS, Ronaldo. Nova face do autoritarismo. O Globo, Rio de Janeiro, 5 dez. 2015.

VIEBERG, Mônica; PEREIRA, Camila. Você sabe o que estão ensinando a ele? Revista Veja, São Paulo, n. 2074, ago. 2008.

VILLA, Marco Antonio. Golpe à brasileira. Estadão, São Paulo, 19 fev. 2014.

ZAHAVI, Gerald. Ensinando História Pública no século XXI. In: ALMEIDA, Juniele Rabêlo; ROVAI, Marta Gouveia de Oliveira (org.). Introdução à História Pública. São Paulo: Letra e Voz. 2011. p. 53-63.

ZAMBONI, Ernesta. Orientações metodológicas presentes no currículo e na docência do ensino de História do Brasil. In: JORNADA ESTADUAL DE ENSINO DE HISTÓRIA, 5., 1998, Santa Cruz do Sul. Anais [...]. Santa Cruz do Sul: UNISC, 1998. v. 4. 